\title{
CHINESE FOREIGN POLICY ORIENTATIONS IN THE NEXT DECADE: WITH REFERENCE TO KOREA'
}

\author{
DAEYOL KL \\ Deparsmens of Political Science and Diplomacy. Lwha Womans University
}

This paper is designed to explore basic ideas which have daminated Chinese foreign policy-making and their implications for the East Asian region, especially for the future of the Korean peninsula in the next decade. For this purpose, the paper attempts to portray bow China would appear domestically or what direction China would mone in its external relations. The conclusions are that, although strategic thinking has been impartant in China's relations with great pouers, societal ideological and historical fators huve been felt much stronger in its foretgn behaviors, and that the future of Korea is beavily dependent on China's perception of the Korean peninsula in this regard 
$\mathrm{F}$ or the past two decades, great changes have taken place in East Asian tegional politics. The following domituating thancs have disappeared since the end of World Wat II: the Cold War; Soviet expansionism; Sino-Soviet dispute; the modenization programs of economy and military in China; Sino-American rapprochement; and the increase of Japanese defense budget. On the other hand, the following have emerged as the frocal points of common interest: mutual suspicion between the United States and China; the nuclear armament of North Korea; and the possible collapse of the Pyongyang regime. These phenomena may indicate the end of the Cold War politics with the coming of a stabke cra as far as regional polities are concenced. In does not mean, however, that all the factors which had conrribused to the instability of the region are elimunated, and this is particularly true for the Korean peninsula.

The region is by no means stable; rather, it is anticipated to undergo further rapid transformations for various factors. The balance of power is not yet formalized as it has been witnessed in Europe, and bilateral relations of the countries in the region have various potcnial for conflict: the conciusion of the Russo-Japanese peace treaty is not yet visible due to the dispute of the so-called northern islands; territorial disputes berween China and Japan, and Korca and Japan have uninterruptedly made their appearances; the future of North Korean regime is not predictable while its relarions with the Unired States and Japan have not moved in a positive direction; and, above all, ever-existing tension along the border berween the wo Koreas is exploxive at all time. The last, but not least important issue is that some of the countries are expected to meet serious challenges from the domestic situation in the near future.

The print in this paper is that China will take a central place in this great transformation of the region whatever shape is is to take, and that other countries are incscapably under its influence, directly or indirectly. This theme is widely accepted and has been currently discussed in Korean academic circles. However, the general trend in these discussions is to treat 'China' synchronically -i.c., regarding China simply as 'a new force,' economically and militasily, in the regional international system. Naturally, this approach is more concerned with the strategic aspect of China's execrnal relations and in this sense deals with some changes in China's responses to the changed external environment.

Of course, this approach is tenable to some extent. All the indices of the economy and military indicate the emerging of a giant in the world political scene, and expect in somewhat cuphoric sense that China will work with other major powers within the frame of existing rules and regulations put forward by the world community. The present leadership in Beijing has also repeatedly assured this point. According to this view, if China becomes involved in conflice with orther powers, it is beciuse China feels its national interests threatencd, or the internarional system cannot adjust to the demands of this new rising force. This is exactly the same point made by some revisionist scholars that the failure of the system to accommodate the revisionist power by the status-quo powvers had 
ulcimately led to the outhreak of World Was 11 (Burron 1967; Pelz 1974).'

However, this approach is inclined to ignow other aspects in China's foreign relations, i.c., socieral, ideological and historical ones. To be surc, China is a socialist country whose value system and world outlook are vastly diffetent from the rest of the world. External relations are bound to impinge directly upon socicty, while political, social and economic changes at home affect orientarion to the outside world. China is particularly conscious of this retarionship; its socialist systen must be kept intact from outside influences, especially from capitalist noms and values. And, for this reason, the societal and ideological aspects have played an important, and rather resmaining role in its foreign policy-making. According to Michat Yatuda (1983, 3-9), by the mid-fifties, Mao Zedong voiced concem that ine largest technological transter in history' from the Sovier Union would make China dependent upon Moscow, a prospect which had eventually unkashed a scrics of political campaigns to eliminate pro-Soriet dements in Chinese society. Of course, ideological feeling has reached its lowcst chb in Chinese society these days, and morcover, the current attempe on the part of China at technology absorption is marked neither by an ideologial affinity nor by institurional similarity, with the foreign supplier. In this sense, the societal aspece has greatly diminished in Beijing's handling of external relations, but canno be igroted, as long as the present leadership trics to maintain the socialist system armed with the so-called 'four principles, '. i.e. socialism, the dictatorship of proletariat, the leadership of the Communist Party and Marxism-Leninisn and Mao 7edong Thought.

Chime also has a remarkable cradition in watching and andysing the world situation, and defining its role in work politics thruugh its own looking-glass. Its world ourlook is no doubt lieavity indlucticed by its own culture, recent history and idcology. No one will dispure the fact that China, as other great powers, follows in the gencral line of prudent realism in dealing with security and other issues of national interest. Moreover, it is true that traditional faciors rogerher with societal ones ate not sufficicnt cnough to explain why and low a social phenomenom takes place at a certain time and in a certain place. Carist Russian cncroachments to China, animosity betwees Mao Zedong and Stalin, or differences in the interpretation of Marxism-Leninisn might be secondary in explaining the Sino-Sortec disputes in the $1950 \mathrm{~s}$ w) 60 (s) we the synobronic and structural factors of intemational politics at the cime such as the diffetences in global strategy and the intraparty relations of the socialiss camp, and border disputes of the two countrics. However, it is not easy to say which are deterninants or contributing factors. Moreover, in the hiscory of Chiness forcign involvement from the Korean War to the recent takeover of Hong Kong, tradition has been felt mose important, and perhaps the ultimate factor in is forcign relations. Thus, this paper is designed to explore somk basic idcas which have dominated Chinese foreign policy-takking and their implications for the Fast Astan regiem, especially for tac futux of the Korean peninsula in the noxt decade.

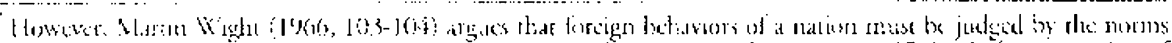

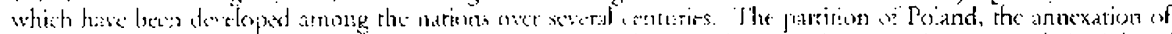

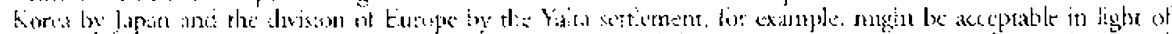

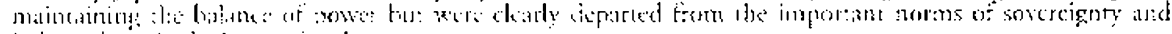

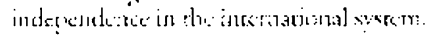




\section{CHINA IN THE NEXT DECADE}

Prior to the discussion on Chinese foreign policy, the shape in which China would assume in the next decade poses a concern. Considering a great deal of uncertainties surrounding China as well as the East Asian region, ic is not easy and even futile to predict or forecast even in a vague term is to what appearance China would exactly take or in what direction China would move in the ycars ahead.

First and foremost, ten years or so are not long enough to change the shape of a nation, much less a gigantic nation like China. History shows that a secio-political phenomenon begin to surface after a long latent period, although society is unable to escape sudden changes by human and social behaviors such as war, natural disasters or developmental plans. Secondly, as tradicionalists argue, prediction seems to be beyond the scope of social science and especially in the field of international relations on a simple ground that a social phenomenon has multiple causations. A recent study by Jarvis $(1991 / 92,39-46)$ atso provides eight reasonable excuses for the inadequacy of predicting international politics.

Since the collapse of the Sovict empire in 1989 and the resultant end of the Cold Wat system, serious discussions have been in progress among scholars in international politics as to why they or their scientific (or Sovietological) models had been unable to predict these events despite the fact that a huge bulk of books and papers on the Soviet system and irs future had been produced (Malia 1992). Prediction on the foreign behavior of a nation becomes all che more difficult becausc the supetpowers and small nations alike, were frevd from the averriding concern for security matters since the demise of bipolar system, and are able to posscss a wide range of choices in forcign policy-making. Nevertheless, it is highly important to predict the future of China, for it is closcly related with one of the main themes in this paper, i.e., the Chinese perception of the world and the definition of its role. Thus, this paper attempts to examine the shape of China in the next decade by muddling through a tunnel filled with extemal and internal complexities.

It is fair to say that China will emerge as a super power, militarily and economically, in world politics in the nex decade. According to recent statistics of the World Bank, the gross domesric prodicc (GDP) of China in 1994 was around $\$ 3$ crillion, a figure which made China the second largest economy in the world after the Lnited States. Apart from economic growth, Chinese achievements were more impressive in the fields of direct foreign investment and foreign-exchange reserves. "A study by Bernstein and Munro (1997), which has touched off much controversy in recent times on the futurc refationship of Chital and the United States, begins its argument with the assumption that within a few years. China will be the largest economy in the world, it is on its way in become a formidable military power as well, and that irs strength and intluence are already far greater than those of any other countries in the vast Pacific region except for the United States.

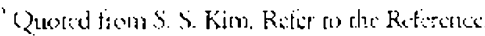


In the tield of military buitd-up. China's ofticial military budget rose to $\$ 9.7$ billion in 1996 , or ahout 1.5 percent of GNP and 10 percent of the total state spending. The official budget has more than doubled in the last five years, and more than tripled since the mid-1980s. Since the Tiananmen incident of 1989 , the military budget has been increased at the rate of 12 percent and more, and especially it was recorded 22.4 percent (or, 11.6 percent of the total budget), which was the highest since Sino-Viemamese War of 1979 . China has invested a large portion of its military hudget in a major upgrading of the combat power of the People's Liberation Army (PLA). The Chinese military budget is not so high, considering the size of military budgrets of Japan and South Korea, and the length of the (Chinese border with neighboring powers (T. I'ak 1996)." As usually practiced in the former Communist countries, however, the official budget has greatly underrecorded the actual military spending, and if all actual spending for military putpheses had becon jucluded, a reasonable estimate of its tnilitary budget would be around $\$ 28.36$ billion, a fugure which put Chinese military spending around the fourth largest in the work (Gurtov 1997; (Gallagher 1994).

Vonetheless, China's future is nor perccived to be bright. The Chinese economy and political structure have been inherently fragile, and no one can predict with any certainty the future of Chinese leadership, policies or international affitiations, even in the near future. These poines are further explored.

It muse be noted that China is virually the only remaining socialist country in the world. Wirh the collapse of the socialist camp in Eastern Furope, the worsening situation of North Korea, the inpending suffocation of Cuha by the tightening blockade of the United States, and the widening estrangement of Vietnatn from China, China has become isolated in the Hobbesian state of nature of world politics. Moreover, the neighboring counnties, especially those in Southeast Asia, which have territorial disputes with China over mutual louderlines or far-off islands, have bocome increasingly atienated from China. These nations wonder about China's intention with its newly acquired power. and are consequently looking for protection from other powers including the United Stares.

In the domestic scene, the situation is more complicated and worrisome. For the past two decades since 1978 when Deng Xiaoping returned to power, China has pursued reform and modernization under the banner of 'sccialism with Chinese characteristics.' 'This is a natural corollary to the slogan of 'Chincse studies (learning, culture, values) for the basc (tiukdamental structure, framework), western studics for use (practical applicarion), a formula by which the Manchu government had tricd in vain to resitalize the agricultural and feudal sociery of China during the last several decades of the nineteenth century (Tong and Fairbank 1971, 50, 169). 'The thrust of their ancestors' failure was that they overlooked the simple tact that various systems wichin a society must have harmony with one another. In the same vein, Malia (1992) argues that recent affairs in Ruxisa since 1989 lave demonstrated that policial transformation is indispensably pre-

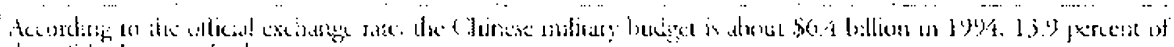

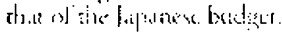


requisite to changes in economic field and others. It is especially true in a monolithic society whese politics are important in every field, and that the first step toward change or the return to normality, is to end the total hegemony of politics.

In the case of China, the dilemma of the present lcadership is also how to practice an 'open-door' policy in which only what it regards as desirable influences are imported, while these influences do not affect China's social norms and life-styles. As long as the political system remains pre-modern and monolithic, absolute manarchism based on the Confucian ideology, which had been contrived over centuries for the agricultural society, and which the Manchu dynasty had wanted to kecp intact as 'the base of the new society, will not sturvive. The prescnt leadership of the Chinese Communist Party (CCP) follows the same ill-conceived path as its predccessors, and this is the fundamental cause of the anrest that the Chinese society has recently undergone in spitc of the wealth brought about by reform measures.

Whatever justification the Beijing government proposes for its policy of 'socialism with Chinese characteristics' or whatever theoretical argument can be expounded against it, the economic achievemett of the past wo decades is stunning. The reform and modemization policies by the CCT' have virtually changed the face of the Chinese society, white uprooting ies very foundation of sucialism. More important is the fact that these policies cransformed the attitude of the people to the opposite of what Mao Zedong and his followers cultivated with great care which was to mold the Chincse into egalitarian socialist human beings who despise material incentives. Corruption has been widespread and most people have pursucd private tathet than collective goals. Indeed, the current economic policics accentuate the promotion of private interests boch in industry and in agriculture. This adverse trend seems to have reached to the point of no return in China as a whole, and particularly in the cities open to western influence. In short, 'socialism with Chinese characteristics' is already in the process of decay or distortion.

The last important factor is dic implication of these trends to the border areas wherc the majority of the people is non-Chincse. Traditionally, people in the border areas took an ambivalent atritude rowarcts the central government in China proper. When they felt threatened by ousside powers, they looked for protection from the central government, while they tried to keep the middle kingdom at arms length in order to maintain their uwo independence. "No visible threats are expected from the outside these days. On the other hand, China has completely destroyed its hope for nacional self-derermination ever since the establishment of the People's Republic of China (PRC) in 1949, a fact which indicates that China is evidently disliked by the pcople of the border areas.

The trend of tampant materialism and moral laxity combined with ethnic nationalism and other elements might develop into a scrious problem. The contemporary history of China provides us with numcrous cases of political and intellectual liberalization, whenever the government signalled to loosen its tight grip on society. The CC.P leadership has been well aware that the intellectuals had demanded the abolition of the monopoly of power by the Communists with the introduction of a genuine multi-party system during 
the Hundred Flowers period in the late 1950s." Secondly, the Beijing government has rigorously pursued the policy of decentralization as part of its modernization and reform prograns. Part of the decision-making power. which had hitherto been monopolized by the central government, has becn elinquished to provincial ot cven Hisiang government and to industrial units. Each provinec is able to make its own devilopmental projects. for which it can endeavor directly and rigorously to invite investment from abroad

Although the social untest in China proper as well as in the toordet regions should not be exaggerated to the extent that it constitutes a chrear to the (CCP's control over the country; the Bejing leadership views it with d great ancern. The govemment saw public order as a serious problem in 17 out of 29 provinces in 1994. Ethnic nationalist unrest, most recently in the Mustim province of Xinjiang this year, is becoming an increasingly complex challenge dex to its anti-govemment and anti-Chinese mature. Mokeover, some hoscite foreign forces, in Beijing's view, have been nanjpulating public/ethnic resentment to subvert socialist Chinese rule under the guise of peaceful evolution (Guatov 1997)

Then, what will be the real shape of China in the early part of the next centary? In a long-term perspective, China might enter the process of disintegration. This may come carlier than anticipated. as happened in the Sowie Lnion. Early in the 1980s, when the revolutionary fever reached its culmination in the walse of the lranian Revolution, some Sovictologists made a very cautoms furedicton that the disinegtation of the Sovict empire might begin by the end of this century. That is the time when a number of non-whire ethnic people. especially that of the Mushims, are expected to surpass the Slav popilation duc to different birth rates, thus, it third of the new recruits of the armed forces will be Muslims in the Soviet Union (Chubin 1480). The fragmentation of the Sovier Union, hosvevet, cane carlier, and forn a quite different direction; from the total breakdown of the conomic system as genctally beticued or from the rise of a new kind of legitinacy as Kirkparrick (1992) suggested.

The case of China might be different. The prescnt authoritarian regime has mainaained that (hinesc socialism is different from thar of the East Furopean countries, when it crushed the Tiananmen uprising in Junc 1989. Morcover, the Chinese system seems at least outwardly to be consolidared with the prestige of the (C.P leadetship being greatly enhanced by material prosperity and strong defense posture. To Deng Xiaoping and his colleagues, who had iniciated audacious reforms to shake oft Sovier-style central planning and state socialism as well as Chinese ultateftist idcology represented by the "Gang of Four under Mas's mante twonty years ago, this tmansition should not be assumed to lead to the establishment of liberal democracy and capitalism. Rather, what is important to these Chinese elites is to consrnuct a more elfeitive and rationalized political system, whether it is democratic or nor. They would be satisfied if China emerges gradually as a stronger power with a slightely dennocratic and plunalized society.

In atditur, thete exist several obstacks to democracy as it recessarily entails the distri-

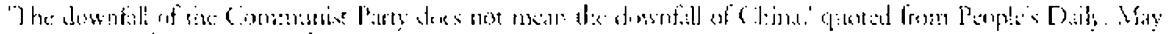

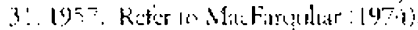

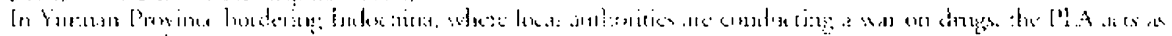
all ist:!pittis:a fuic:
} 
bution of power and influence in society. In other words, democtacy is bound to lead to the dissolution of the present one-party system, a phenomenon for which some conservative sections of Chinese society and the present leadership are not yet prepared. For example, those on the state paytoll, especially state-sector industrial workers, low- and middle-level party and state officials, members of the police force, and the military, have had reason to feel threatened by, and are openly hostile, to the economic and political reforms. Moreover, the chief proponents of democratic reform which include students, intellectuals, and new entrepreneurs or businessmen are small in number and less organized; they do not form a coherent political body or novement, they are in a sense among the most favoured beneficiaries of the Deng Xiaoping reforns, and therefore should be relatively content with the status-quo. Furthermore, as the individual members of such groups are generally quire dependent on the state for their personal careers and future, they have to be careful critics at best, or express more complacency than protest. for democracy. Thus, given the composition of conflicting social forces and the available options to current political power-holders, a normal or smooth transition to democracy in China seems to be remote (Shue 1992).

If democracy is a remok possibility in the Chinese policical and social milieu, China might be engulfed in the political turmoil as was experienced in South Korea in the 1980 s with much more complicated policical, demographical and ethno-national problems. This transition can become very violent to the extent that the present regime cannot cope. Shue (1992) suggests that the present era is most reminiscent of the last years of the Qing Dynasty which lost legitimacy by its failure for teform, thus, igniting a nationwide movement for policical renewal and cultural renovation. Just as it happened in the last days of the Qing, the toppling of the CCP regime would come suddenly with a rise of a military man or a popular regime like Yeltsin in Russia, but this course would not necessarily speed China toward democracy, as in the period of "interregnum (191149)' in China.

For the people in the border areas, democratization and decentralization are considered to be a kong awaited opportuniry, and the best mcans for them to achieve their cherished dream to become frec from the Chinese rule. With the disintegration of the Soviet Union, Muslims in the Sino-Russian border have already achicved independence, and attracted their brethren inside China; Mongolians, whose land the Chinese used to call 'Outer Mongolia,' and who have succeeded to some extent in expanding their diplomatic relarions, became the ladestar to their compatriots in 'Inner Mongolia'; in the southwest, the people in Itibet have never abandoned its hope for independence from the yoke of China.

Beijing views these phenomena as a concerted plot of the anti-China factions in the West headed by the United States to split and wcaken China by giving support to scparatists in minority localities and by exerring pressure on such issues as demecracy and human rights. Thuss, the Chinese response to these trends is firm and harsh. The $\mathrm{CCP}$ leadership did nor agree that the people's cry for democracy as shown in the Tiananmen

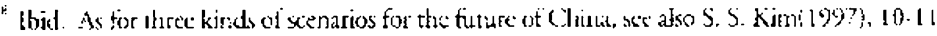


demonsuration in 1989 was insurmouncable. Deng and his followers crushed this demonstration in honor of the reform-minded leader, Hu Yaofeng, in blond-thirsty manner, as if the movement had contained antagonistic contradictions between people and reactionarics in terms of Mao's famous thesis of 1957 . This was an unprecedented step taken by the CCP in its history. Mao and his colleagues chamed proudly that they had sought uniringly to solve contradictions among the people by peaceful means such as thoughe reform and self-crivism contrary to Stalin's method of bloody purge in the 1930s." The. Tiananmen massacre was in this sense unmistakahly a deviation from the C.C.'s tradition.

As for the border areas, things have been getting worse from the Chinese point of view; as the world trend for sclf-detcrmination, democracy and human rights has long been opposed to the latter. Thus, there will be more complicated problems for a considerable period of time in the future. However, Beijing has determined not to allow any sort of disturbances to chereaten the CCP regine, and consequendy, it did not hesitate to adopt extreme means such as anti-crime campaigns and execurions in provinces in connection with anti-government riots and other criminal charges such as violence against public. officials, banditry, smugghing and corruption.

\section{CHINESE PERCEPTION OF THE WORLD AND FOREIGN POLICY ORIENTATION}

The making ol foreign policy begins with the perception of the outside world. Man or personified state reacts to the outside environment, which does not exactly correspond to the real world. but to his perceived inage of the reality. This pattern of behavior is manifested more prominendy when a state is guided by its own self-imaged role or ideology, and is especially true in the case of China. Since the foundation of the People's Republic of Chim (PRC) in 1919, China has habitually drawn the world political map through its own looking-glasi. During the early days of the Cold War, China viewed the world as divided into no rival camps led by the Lited States and the Soviet Union. China itself was tightly encircled by the aggressive, imperialistic, capitalist United States, and therefore, had to lean to the side of the Soviet Union, due leader of the socialist camp. It declared no middle road. However, as the strategic association between the United States and the Soviet Lnion grew, as the formes pursued a harder line against China over Tawan and other issues. and as the later's dispute with China began to intensify in stratcic and ideologicil fields towards the end of the $1450 \mathrm{~s}$. Bejing concluded that the revisionist Soviets have joined in the anti-Chinese onspiracy, leaving China the sole bastion of socialisn?."

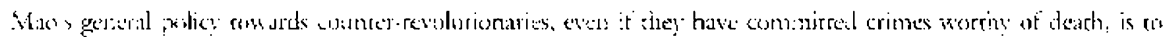

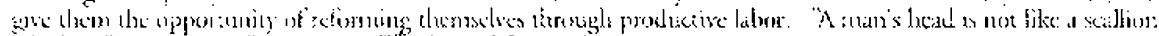

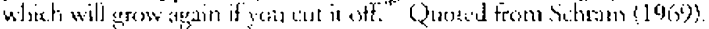

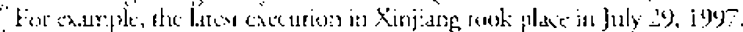

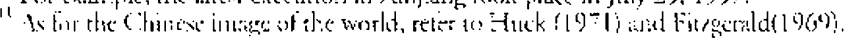


The atritude to analyze and interpret the world situation through its own inuage has been continued even after China cmerged out of isolation to become an acknowledged, full participatory nember of the internacional diplomatic system in the carly 1970 s. When Deng led the Chinese delegations to the General Assembly of the United Nations

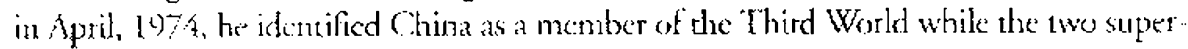
powers and other industrial nuations comprised the Fitst and the Second World tespecrively (Yatuda 1978, 240-2441.:

Nevertheless, the inage of the world is not the only criterion for the Chinese in its foreign policy-making. Morcower, the image taken by China is not exacty identical with the reality. By and large in is colored by ideology and necessity of time. In this respect, lowe

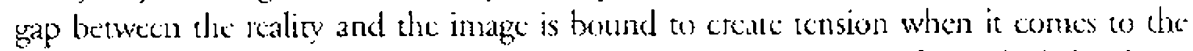
making of lorign policy. The Chinese has fully understond this Fact, which has been prominintly disphyed by its handling of foreign relations in corms of Realpolitik ari-itiris other great powers. Since the foundation of the PRC, the Bcijing government used to cscalate tension oxer surategic ind ideological issues with the two superponers. Except for the Korean War, however, China never artempted to clash directly against any of the two superpowes. Even in the Korean War ahe Communist egine which had just declared (be establishment of a new (hina, dispatched voluneces in order to avoid the inepression of derece military contrentation agaistst the 11.5 . forces in the hostilities in the pertinsula. In the subserulent events such as the Taiwan crisis in 1954 and 1958 , whe border disputes with the Sovien snion in 196\%, and the Veromanese War in the 1960s and carly 70 s, the Beijing kiadershig successlully managed confrontations eicher with the Lnited Saltes or the Soviet Union under its control. Thus, for the convenience of analysis, Chinese approach o its external relations can be divided according an these iwo differenc backgrounds from its past and tradieion, and from prodent ralism.

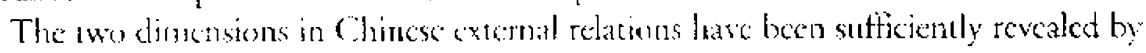
iss handling of external alfair of course is is unable to distinguish which chinese foreigin relanions issue belonge to whith dimonsion; every jisue has two aspects at the sarme cime and the difference is nore a nater of degres. However as discussed earlier. a sense of isolation, suspicion of the West and eagerness for the return of lost territories, including 1 tong kong and litiwan, definitely belong to the first categoty. This implies

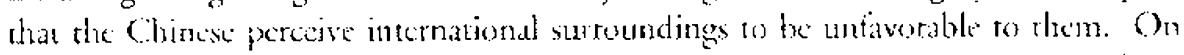
the othe hend, from the realist perspective the global and regional comironments tave gratly improwed since rhe 19:0s. Vow Russia is unathe ro pursese irs expansionist policy dise to the collapse of its anomy, as wall as the independence of reputhlice in the berder regions. Thus, milicary tension brought about by U.S.-Sovet and Sino-Sovier controncations in the Astan and Pacific region has diminished to a great extent. Moremer, napprebemem between the wo continental powers has been underway; from the Ruscian standpoin it is ssemral in promote bilateral trade with China for its

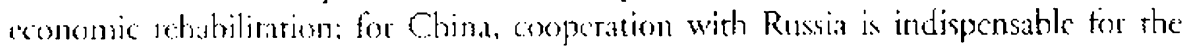

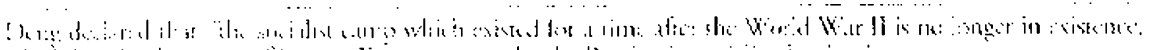

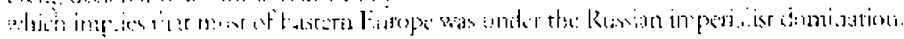


maintenance of peaceful environment in the border region as well as for thwarting American hegemony in strategic and economic fields. China's relations with the United Statcs has been steadily improved since President Nixon visited China in 1972 , a)though outbursts have broken out occasionally from Washington and Beijing over the fawan and trade issucs, and despitc the fact that China has not ultimatcly shaken off the distrust that the United States has been desply engaged in conspiracy for the disintegration of China.

One of the prominent aspects with regard to the Chinese past is the rise of Chinese nationalism. This is probably the single most important element in the realm of foreign policy-ruaking since ideological interpretation began tos lose its momentum in the late 1970s. It is a well-known fact that over thousands of years, the Chinese state developed more or less autonomously and self-sufficienty, while foreign or 'barbarian' influences werc either neglected ar aborhed but viewed cynically. This culture-based 'Sinu-cencratism' was thoroughy shattered by the 'ccnury of humiliation' inuposed by the Wesc, and later by Japan from the Opium War in 1840 until the establishment of the PRC in 1949. During this painstaking period. China's culturism was replaced by, or transtomed into, nationalism. Even Chinese Communism is regarded as another expression of nationalism, as shown by the lace that Mao Zedong had strenuously upheld the principle of the Signification of Marjism' duritg the years of the SinoJapancs War before World War II (Bianco 1971, 50; Schuram 1960, 171-173). And, since Mao declared in September 1949 at the Chinese People's Political Consulative Conference thas 'China has strod up, the Beijing govetnment determined that 'our nation will trever again be an insulted narion' (Schram 1969, 167 168). Now nearly 50 years have passed, and both China and the world have undergone tremendous changes. However, the undercurrent of the Chinese foreign behaviors is nearly idencical to the abrive statement

'Socialism with Chinesc characteristics' or 'Chinese way of socialism' is vicwed domestically that the C.C.P leadership wanrs to keep the present socialist system while toleraring the introduction of apitalist elcments such as market economy. In external relacions, however, this term is closely integrated with the phenomenon of the rise of Chinese nationalism. Chind has already discarded its traditional world outlook, in which China oceupies the concer whike other contries in the periphery pay the tributary mission to Beijing. The Chinese notions have now heen definitely replaced by Western noms such as sovereignty, independence and equality among nations. and China has behaved itself as a grear power similar to the notion of a great power in Furope. In this completely different international syscem, the pursuit of 'Chinese way of socialism' is norhing but an explicit expression of reasserring China's greatness and establishing a Chinese centrality in world aftairs (Yathuda 1983; Schram 1969), 160-61).

Territorial dispunes with ncighboring countries and tension over libwan with the

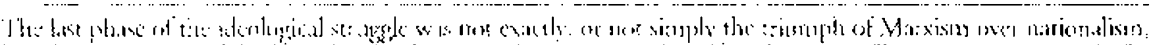

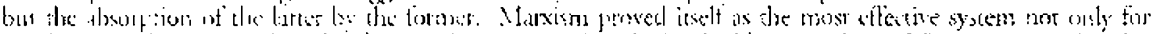

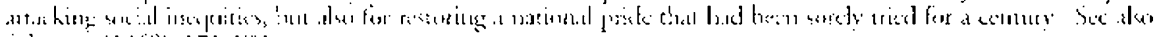

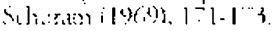


Lisited States might be explained in the same vein. What might be called the Chinese irredentism is just one of the ways the Chinese has cricd to recover its national pride, deprived of by the W'st during the past century. In the raditional Chinese workt, the border between Chira and the outside world was looscly delineated by wone/belt of land such as the Cobi Desere or Himalaya Mounsains rather than a line. According to the Chinese vicw in addition to the reritories taken from China such as Taiwan, Lju-ch iu (Rvukyu) Istands, parts of Xingjiang and the Amur basin, thẹ Western and Japanese imperialists drew lines berween China and their colonies including India and Indochina in the latters favor during this period. These injustices which were incurred upon China muss be corrected.

China has been quite adanam about this mater, and has been unlikety to be conciliatory. Since the stablishneat of the P'RC, China fenghe wo wars against India, and sent nne 'punivive expedition to Viernam, which was once a socialist ally, over border dispures. The recent 'unification' or 'handover' of Hong kong was also an excellent opportinity tes observe this atcitude on the part uf the Chinese leadership. Since 1484. China and Britain bave negotiated the terms by which the latter would hand over Hong Kong to the lormet. At the titne, it was widely speculated that China would get more henefits if Hong Kong would have remained isn the hands of Britain, an idea which made China nor custusiastic in the naater of the libcration of the conclave. I Iewerer, the Chinese handing of affairs in Hong Kong in the last days under the Lnion Jack. stech as the dissolution of the elected Legislative Council under the auspices of British colonial government and the indirect cncouragement of self-centorship of media. showed that in would not compromise and allow any sort of intervention tron other powers when its sowerignty was at stake. Beijing's firm stand is not expected to be amslionated in its creament of affairs in this 'Speciat Administrative Disurice' in the future.

The isse of Taiwan is probahly the hest example which showed the wue nature of Chinese forcign policy combining nationalism and practical Realpolicik. As was commented in a study by Tucker (1996), no issue in China's forcign telations, especially with the Linited Srates, has bxelu as dangerous und divisive, or has had the devastating impact as the Taiwan question. This is precisely heciuluse the Taiwan question is closely telated to Chinex natrondism. It has been the symbol of Chinest humiliation as it was deprived of

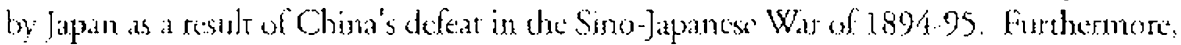
rhe istand was mor returned to China after Wortd Wa II since it was oceupid by the Kiwmintang (KMT), butressed by the Lnited States. The recent devclopment of the istand's indepeadence mowement by jts native people headed by l'resident Lee Teng-hui is not snly a continuing altrent to China's national pride, but also a ral security prob$\mathrm{km}$.

Despice be repeated requeses of the Linjed States. Chinat has never renunciated the use of force against Faiwan, because according to the Chinese argumene, it betongs to the realm of sowereignty. And the Chinese deternituation over this issue has been fully demonstlated by its military cxercises involving missile cests just aorth of the island in 
1905-96. Ot course, these operations were designed to thwart the slightest move for the island's independence and to warr against the L.S. government's encouragement. 1 lowever, China's handling of the issuc has been ational and prudent as well. Its formula for solving the Taiwan question is the so-called 'onc country, multi-systenks, which secms, to the eyes of the Beijing reginne, to have been applied successfully to Hong Kong in the summer of 1997 and is further applied to Macao in 1999. Under this system, Triwan would be allowed to run its domestic affairs and to possess its own armed forces, while subjected to the central government in the management of forcign relations.

Although the (hinese offer might be considered generous and liberal, 'lawwan is not prepared to acespt it. In short, the Taiwanese are not rady (o be subjugated to a coonomically poor and politically dictatorial sysem in the continent. There has been a growth of a yerunger gencration of Taiwanese. who does not have much affiliation with the mainlanders and wasts to uphold the principle of self-determination-i.e.. Tawanese independence. Nevertheless, the Iaiwanese does nor risk to renounce the 'one China' principle which the KMI has maintained since its retreat to the istand in 1949 . On the other hand, dhe labuanese have also become more indifferent to the issuc of unitication. They sec lie unitication as a long and gratual process, during which dicy expect democratization in the mainland to he advanced to the leve] in Taiwan. At the same time, the Taipei gewernment under the native leadership of tee Tengahui is accelerating its bid for international recognition and for assuming a larger rolo backed by its economic power. Thus, the lawan question will not be solved in a short time, as long as the laiwanese enjoy a high degrex of prosperity, and the United States does not atbandon the present policy of preventing Clina trom the use of lotse against the island. The unifieation of Taswan and China, in shis sense, witl be poscible when the poople in the istand belicwe that we political system of the mainland is sutficiontly improved to protect themselves from the ryanny of the Communist dictatorship. As for Chima, this signifies that the onty and best way is to be ready to accept the status-quo across the straits for the lime being, while w warn Tapej uninterruptedly against any move in the direction of selfdecermitrations.

Whot it cones to China's cxtcrmal relations from the perspective of readiom, its retathom with she United States is the most inportant. Acoording to the concepuatization in internationat relations, China is considered a revisionist power in the region regardless of the rherorics cmployed by the leadership in Beijing designed tor its foreign policy oriontation to be puaceful. To be a terisionist in international relations, it means that a state is discontent with the prevailing international system, and pursucs policies to change the system in is favor. Its resurgen nationalism. as described above, demands implicitly and explicilly ins tightiful place under ths suth and it has been backed by China's steady and vigorous armament programme of its armed forces and by its stunning economic groweh in the past several decades. Morover, neighboring countries are alteady watching Beijing's moses with great concern.

Of course, the theory of the Chincse threat is not indisputable. First and foremost, during the Shanghai Communique with Nixon at the Bandung conference, and l)eng's 
speech of 1974 at the (Jnited Nations, the Beiging government has tried to assure neighboring countrics that Chind would never seck hegemony in the region, and that China noeds a peacefial enviromment for is ceonomic development. It is probably tuc and trustworthy for the rinc being. Some sholars also arguc that given the constraints posed by the deficiencies it the (Chinese modern milicary technology and by domestic and intemanional situations, the formes of which had been partly proved by the PLA's poor perfornance during its 'punitive' expedition of Vietnam in 1979, (hinese threats to neighboring councries in Sourheast Asia are 'illusory' (Gallagher 1994, 169; 1 . Kim 1997). Another study by T. Kin (1997) also concludes brat, considering the credible capability of Chima, the will to ase its armed forces, and the acepentec of Chinese hegemony by other puwers, a hegemonic (hina' theme is a premature and alarmist view ro some extent, thus. the study requires a carefil examionation. In other words, its miliary modernizarion is far hehind the standand of the Western powers. a face which was evidenced by the (iult War, and gave PLA leaders a great concern.

I his argunest is partially untenable. Finss of all, the tealist of international politics is more concenticet with the capability of its enemy's contemplated rather than its pro.

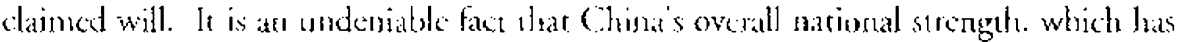
dramaticaly increased in the newrly twenry years of economic reforms, misde it an acrual security threat on its neighbors. To them. Beijing s gesture and will for peace is secondary ti) che actual capability which China can wield in dealing with thenn. In other words. mobety an guatrantec that Chinat will maintain its policy of cooperation and acommodation in the next decade. It is also evident, as indiated in the recont crisis in the Laiwan Sodis, that Beijing woukd not hesitate wo use, or threaten to usc forec

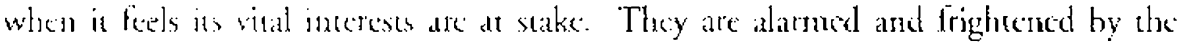
prospece of Chinis potential power combinet with irs nationalistic assertion and cul. tural dominance in the region. and are looking askance ac the true intencion and furure role of (china in world politics. In addition. the interionity which China feels vis-ia-vis the Western prowers in mulicary technology carries litule weight because is military

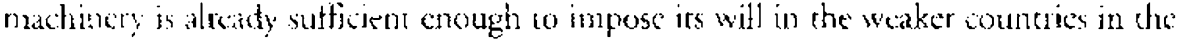
region. Exen for the secan powers of the region, the future of Chinese miliary capabiliy has become a scrious concern because the modernization of the PLA. especially its

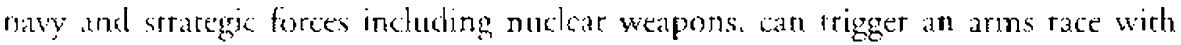
Japan. This is a siruacion which, in turn, might lead ro a nuclear-amed lapan independene of the Linired States. This scenario is a nighemare not only for China itself. buc also for whe' grtar powers including the United Stares and Russia, and tor all Asian und Pacitic sotumes which have experienced lapanesc milicarism in the first balt of chis centum?.

If Chind is at revisionist. it is incsitalite that other powers will to to prevent Clunis search for dominarion in the region, and to seck assistance from the Lnited Stares. Here. we cali spuculace the pessibility of a chash lerwern the Inited States and China. One such theor was prowided by Samuel I? Huntington (1943) with the name of the clash of civiliaations. According to Huntington, world politics is cntering a new phase ater

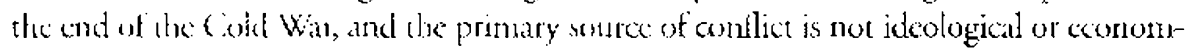


ic, but cultural. In historical perspective, he argues that conflict hetween civilizations, which he terms as cultural entitics, will be the last phase in the evolution of conflice in the anedern world. Ife also argues that civilization ensity will be incroasingly important in the future, and the world will be shaped in lange measure by the interactions among seven or eight major civilizations including Western, Confusian, Japanese and Istamic. Here, non-Western civilizations have attempted to modernize without becoming Western, and ro date, only Japan has fully succeded in this quest. Though a clash berween the United Sates and China does not come to the fore in his thesis, he clearly understands the prescne contlic and cension across the Pacitic and Beijing's ruthless policies in the border areas, indeding the Budkhist Tibet and Muslim Xinjiang. The nilitary burild-up in China, and the exprerting of nuclear materials and missile technology to Arab comntries, are by and large an anti-Westem of Confucian-Islamic coltaboration against the West according to Huntington. He cven anticipates that in the future, the principal Fast Asian conomic bloc is likely oo be centered in China along with its close echnic and Confician neighbors.'

Another study also points out the possibility of collision berwen the wo powers in a similar context. In the abence of the East-West conflict, Samucl S. Kin (19)?, 7) nores that Sino-American relations have become increasingly tense, and one of the sources of conflict is their traditions in exrernal relations. The U.S. exceptionalism such as America's manifescation in destiny and the extension of American liberal empire which is expressed in the form of human righes diplomacy on the orher hand. and the Chinese middk kingdom complex, which is basct on is great civilizarion, and on the betief that che Chinese state sovereignty is excmpe from international rules and noms.

Humingron's argument scems to be acceptable to a certain cxtent. In the breakup of former Yugonlavia, che policies of Western Europeas countries and Russia can be explained in rerms of their atfinisies with religion and civilization. It has been also noted that intellectuats in the West have rather kept silence or at least caken a low profile about the nassauce of Muslims by the Serth. It is comerasced conspicuously to the outeries or acrive participation of Westem intellectuals in the independence moscment of Grece: and Bulgatiat from dhe Onoman Empire in the last concery during which local Christians had becn high-bandedly acared by the Muslim Tarks. However, in the East $A$ sian the ater, is is harbly experted that Chilat ungether with other Confucian and non-Western countries, induding lapan, would unite for a common cause against the United States and Europe. In the mind of East Asians. unity would incuitably lead to the domination of Chinta an assumprion which they would never be mady to accept. They are more liksly to try to maintain the balance of power agains the gigantk China by aligning themselves with the Lfaicat Stakes. if individeal naxions are ner strong enough wo have leverage wis-it wh China. Here, their policy will be guided more by the consideration of sccurity and other national incerests than by the attinity of civilizarion.

Another theory of Sinu-American clash stasts with the assumption that China is actual-

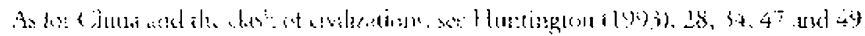


ly or potentially a revisionise power. If China is a revisionist, the policy aiternatives open to the Unitcd States are cither to introduce Beijing to the chl of satisfied status-quo powwa by unecring its demaunds or to encircle. China by containing its denuands in the Cold War context. It is cmeirly up to the Washingon government to judge whether Chimats demands ars moderate for, and compauble to, U.S. interess, or China, as a leading power in the Fast Asian ragion, is entitled to daim its plate in world affairs or China is too harmfiul to maintain peace and to protect U.S. interests in the global and regional levere. Presen debates on Sino-American relations can be understood in this context.

The so-called engagement or containment was first expounded by Joseph Nye Ir. (1995), then the Assistun Sectary of Delense for Intornusional Security Alfairs, in his atticle. Fast Asian Securicy: The Case fur I Jeep Engagement in Forcign Aflairs. Being reminiscent of an arrick written by $X$ (1947) on the Soviet foreign hehaviors hall a century ago in the same joumal which ushered in the age of Cold War, Nyc's argument in tavor of engagemenc policy has streambined U.S. policy to Asia and particularly to Chind. In strert. Nye argues that the United States should mantain the present level of L.S. cropes in Fast Asia. In spite of the face that the world after the Cold War has

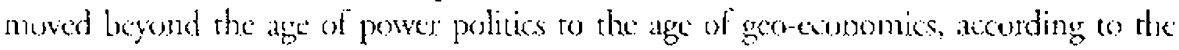
Assistane Secreary of Detense, this nartow geo-economic andysis cannot provide a ra. sorrable socioleginil frame for geopolicical necessitics ro deploy a forwat military preschac in the Asian soil.

Nyc aptly describes that the periods of the rise and fall of great powvers are often times of greal instability in international state systems, as indicated in the Peloponnesian War, French Revelutionary Wars and the Wortd War l. He views thate the international fower structure in Fast Asia today is similarly unatied by the tioc and fall of grat powers, as witnessed in the decline and collapse of the Soviet. Union. the consunued growth of Japan, and the conomic rimstormation of China. The tuture problems of the region are. therefore, the adjustnent of the international system to the rise of Chima's power, the eventual rejurenation of Russia, and the evolving role of lapan as well as the reduction of tersion in the Korean persinsula. Considering chat the United States is the only global and coumonic power in the region and that multalated institutions in East Asia itre rala-

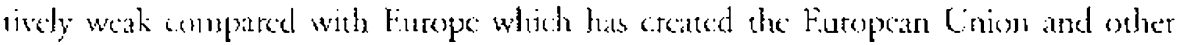
inesnational organizations aver decades, U.S. policy to the Asian regron, muss bo 'engagement and cribrgemenu.'

A strong and unswerving American leadership supporred by the presence of U.S. troops in Asiz. is a vital element in the policy of engagement. From the view of the Assistant Secrenzy of Detense, this policy of mainraining a stable level of troop strenglh des nou mean of perpetuate dxe (Cold War in Asia; morcover, it is cheaper for

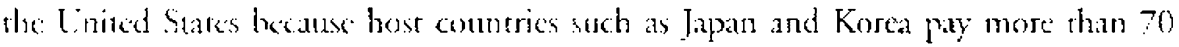
pereene of the troops werall costs. Insteid, he considers the creation of a VATO-like regiomat alliance wo be a mistake in East Asia since it does not have a long tradition of regionial cooperation. Nye strongly rejects the idea to portaty China as an cheny, or to contain China on the ansumprion that Chima will be aggessive to outside of the

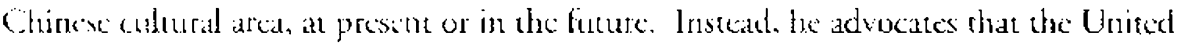


States must try to engage in a dialogue with China on a broad variety of fronts. This policy of engagement has already produced some progress in the ficdds of proliferation of weapons, multidateral regional dialogues and confidence building measures between the two powers.

However, the point is that no matter how good intentions the Inited States has vis-atis China, Chinese perception of L.S. forcign behaviors is entirely different. Henry Kissinger, the tormer Sectetary of State of the U.S. government, warned that: Once China becomes strong enough to stand alone, it might disciard us. A little later it might even turn against the United States, if its perception of its interests requires it' (Kissinger 1979, 1091; Bernstin and Munro 1997, 22). In fact, lhe notion that the United States is China's main rival and enemy, is widespread among official and non-official circles in China. As a result, discursive languages which describe dark schemes about China by the Inited States have becen constantly pouring out trom Beijing, To the eyes of the Chinese, the main rival of the United States at present is the PRC, based on its global hegemonist strategy. High-kevel government officials used to perceive that interfering in China, subverving the Chinese government and sorngling China's development ate strategic principlos pursucd by the United States.' Becaust of this, Armericau hegemonists have interfered Watantly in Chinese internal affairs and supported openly the debilitating activities of hostilc elements inside and outside the mainland, subverting China's socialist system (Bernstein and Munjo 1997, 22-25).

Of course, this atritude in China reflects a sort of besieged mentality in a world where China feels isolated and that everyone else are ganging up against itself. However. Beifing's official policy does not cotrespond to the above statencents. In this sense, Chinese atcitude has becn contradictory. It is undeniable that the Unjted Srates is one of the most important sources for Chinese economic development, by providing the market, capiral and technology. Noreover. China does not hide the fact that it regards Washington as a strategic partner in great power politics. On the other hand. Chinese history and foreign tradition tell ws that their suspicion of U.S. intention does not merely stop at xenophobic expressions because the collapse of Chinese dynasties was often brough atrou by collaborared efforts of domestic discurbanos and foreign incursions. Domestic uneses enconraged barbarians in border arcas co invade the Chinat proper: while fotcign encruachments provided dissatisfied elements inside China with an upportunity to take an anti-governmental action openty. Accordingly, as long as the present CCP leaders feel uncasy about the future of China due to the democratization of its society, the decentralization of provinces, and the self-determination of the people in border areas, they will inevitably urn atcention to outsiders who could give support to anti-governntental elements inside China. Naturally, the United Stares comes io forre.

In this respect S. Kim's $(1997,10)$ argiment that the future of China is as much dependent on U.S. approach to Chinese affairs as domestic devetopment of China itself is not quitc convincing. Of course, it seems trus that as long as Washington's approach to China is benevolent, it can be conducive to friendly responses from Beijing, a task which policy-makers in Washington hope to achieve. I However. to the Chinese, the L.S. han- 
dling of Chinesc affain today, sich as haman rights diplomacy, ban on nuckar technology sales to the Third World. ase wroll as the Taiwan issue, is not benevolent or friendly ar all. Jo the [nired Srates, human rights are one of the universal values which must be pursued by the coumeries all over the world regardless of parochial national customs and caditions; ban on the cxport of nuclcar materals is the comerstone of U.S. foreign policy in the post cold War era; "aiwan is a hiscorical legacy inherited fiom their murual relaciens. Howeser, to the Chinese, these issues becm to be designed to undermine the

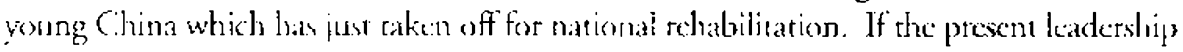
is confiden at the smooth evolution in such maters as the demonatizarion of the Chinese veitey and solving the ethnic problem in the border areas, it might refrain from a hostile and ancagonist same ris-atis the United States, and treat bilateral issues raised by Washingesn on the at bo basis in a rational manner. Thus, it can be said that SinoAnkeriun relations in the future is very dependent on the developnent of the chincise domestic semes.

\section{CONCIUSION: CHINA AND KOREAA}

China's polio towards Korca is decermined by a variety of elements which has been operated on different amensions of the imertatronal political sysem. These include: the China's stracegic concepe in which the Korcan penisula constituces an important part; its relations with other powers in the Fast Asian region; its idcologkal propensity which makes the Beijung regrmo regard J'yongyang as a socialist ally; Chinese domestic political situation in which modermization in the dedds of industry, agriculture and technology is important; bilateral relations between Bcijing and Seoul; and above all, North-South relations in the Koren peninsula.

Thadionally, China Korean policy has been based on one principle: China should keep a grip on the peniosula and elininate de intuence of other powers from this stratc-

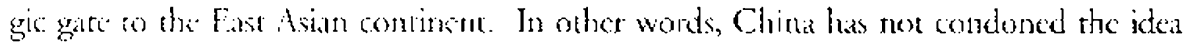
that the peningtala poses a threat to its security as happened since the last years of the nineternth ontury. This strategic consideration is still valid and perhaps a big dream in the Chinese strategic (hirking, which China wants te achieve, if circumsances purnitted. Early in 1945, when hostiliry in Furope was juss moving en the end, and China was not strong conough to repulse the lapanese amy in the Astan ontument. the Nationalise

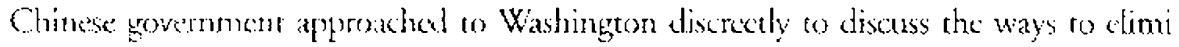
nate: the persibility of Sovict involvenone in Korean aflats after the siarender of fapan. In reility. China aimed at the restablishmene of China s hegemony over the peninsula with the support of the L'nited States. This strategy failed partly due to the incipabilicy of Chima and paraly due to the arlier involveneent of the Soviet Red Army in the Far East fForegn Relations of the linited States 1945 :

This episode shows us what China, whether a Nationalist or Communist, aried of

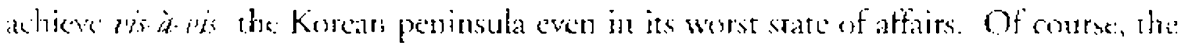
internarionat policics surtounding the Kutean peninsula we entirely different fiom the 
past, and other powers including the United States, Russia and Japan also have a legitimate yoice in Korean matters, since the peninsula is included in each power's security sysicm in the region. This implies that the peninsula is no longer a monopoly of China; rather it is an arena where China interacts widh oller great powers in the region. Apart from great power politics, the Korean quescion has also evolved over bilateral relations between the two Koreas. The competition between Sroul and ['yongyang in the fields of legitimacy, nation-building and economic development was largely by the end of the 1980s, when Seoul succecded in gaining diplomatic recognitions from the Soviet Union and China, while North Korea was on the verge of econumic collapse. Thus, Sino-Korean relations cvolve over multilateral relations among the great powers interested in East Asian polirics on the one hand, and over two Koreas' telations on the other. 'These two dimensions, regional and local, have been tightly interwoven, as the peninstila bas been one of the focal points in regional poliiics.

The bilateral relations between Beijing and Seoul is added as a third dimension. This aspec has been largely ignored since the Suuth Korean economy was shattered during the Korean War, and it could noc play a meaningful role in regional politics, while China, the staunchese supporer for the lyongyang regims in the Cold War, was nor ready to arcept Seoul as an independent actor. However, with a rapid economic development in South Korea during the past several decades, rogether with great expansion in trade between the two councrics, China could not but ralize the fact that the basic interests of both China and South korea have become more congruent than divergent. (hina finally came to the conclusion in August 1992 that relations with Scoul should be normalized. In this respect, the growing connomy of South Korca was vital in bringing its new status in regiental policics.

Sino-South Kurean rade has sceadily riscn from $\$ 498$ million in 1984 (approaching the level of China's trade with North Korea, $\$ 498$ million) to $\$ 3.1$ billion in 1989 , a year after the Olympic Carnes in Scoul. In the 1990s. China has emerged as one of South Korea's most important economic pattners as well as one of its major competiwrs. The volume of trade betweer the two countries has reached $\$ 16.5$ billion in 1995 . Ihis figure is 30 times more than China's trade with North Korea, and China became South Korea's third-largese trade partner after the United Staces and Japan, while South Koren was China's fitth largest trade parner after the United States. Japan, I long Kong and Tawwan. In 1997, the tural wolume of bilaceral rade recorded $\$ 20$ billion, and is expecied to grow at an average annual rate of 18.9 percent in the $1997-2001$, reaching $\$ 56$ billion by 2001 (S. Kim 1997, 15-6). Thus, though limitcd, South Korea is not only able to provide (hina with capital and technology for its modernization programs, but also to serve Chinesc efforts to diversify its overstas markets, which has been overly dependent on the l.S. matket. Presently both couneries have begun to togard each orher as a potential partner against growing economic protectionism in the lonited Srates.

Sino-ROK economic cooperation has also borne fruit in the political field to some extctt, as China has firmly committed to the maintenance of a peaceful envitonment in 
East Asia, and especially in the Korean peninsula ats a prexequisitc for its modernization programs. This policy of Beijing would be a valuable asset for Sooul in preventing the Pyongrang regime from taking military provocation zyairst the South. Morcover the Chinese decision for normalization eliminated the las barrier which had restricted Sond in its diplomatic font. Seoul has already received a gren light from Bejijing in August 1991 when it succeerted in making breakthrough in the long-standing issue of the two Korcas membership to the United Nations. This served also a salutary warning to North Kurea that l'yongyang should abandon ies yuest for aboshute stand for international legitimation, namely, dee one-Korea policy:

However, this is just one side of their telations. In the beginning, the Sino ROK economic relations, which have a aid a foundation for thes mutual cooperation, are not so bright in the future as might be expected. One of the most serious and gloomy aspects is that the nature of their economic cooperation has changed in recent vears trom complementary on comperitive in the world matkes ln the political field. China's policy ro Korea is, in ank sense, conducive to the statsility of Korea by its gatarantec of peace in the perinsula, bus has a poential, ia another sense, to carty negative conseguences to both Kureas. For Vord Korea, Sinc-ROK normalization means the koss of ic: last remaising supporter for intornational legitimation since Bejing agrecd with Seoul's wo-Korea formula, which Pyongyang had strenuously rejected. Of course, Beijing sill maincains its alliance pace of 1961 witl Pyongyang, because North Korea is still ingertame for C.hina's defense of its policical center of the Beijing atea and northeaseren provinces. However, Pyongyang rogards that China has alreddy tilted on Semul atrout the Korcan question, and in this respece, Pyongyang is suspicions that Beiging will gatng up against Vorth korea with Scoul and Washington during the tourparty talks.

For the South, Chinese penchant for Seoul is of limited nature, being a sort of balianc ing ace w the dhanging intcmational situation. Normalization meant neither that Beijing ahandoned Pyongyang, nor that bouk sides could find a common ground to solve the'

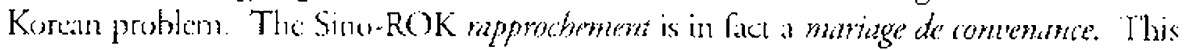
has been amply manifested in China s handling of the nuckeat problem of Nenth Korea. which had began to emerge just affer the inusgararion of the Kim Foung sams gonernmem in Fehruary 3993. China, sne of the fire permanen members of the $6 \mathrm{~N}$ Secusity Council, never agred wo any drafi resslution put forward by the United States and Koreat toggether with other Council members, which can be interpreted as a sanction against the North. Theregt China has detined its pessition as lavoring negotiation and dialogues os

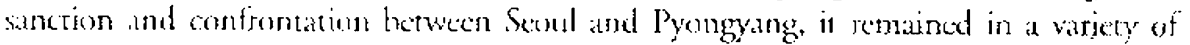
ways a supperter for the caltse of the lyongang regint. This shows, on the anc hand. she big gap between the approakes of Seoul and Beijing to the Korean question. and on the other, the fact that Chine would not lose any leverage in future developments of the divided Korcia.

l'erhaps. ithe mantenance of leverage is a minimum requirement in China's Korean

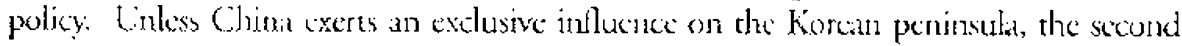

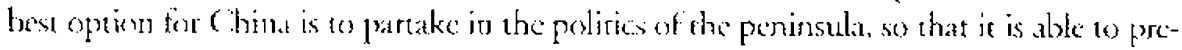


vent a situation in which the peninsula becomes opposed to the Chinese interest. For this purpose, China is ready to seck a coalition with other power(s) in order to deter the expansionist trend of an allegedly dominant power. In this sense, the Korean peninsula is a scene where China can experiment with its strength with oulher puwers. At prescnt, two rivaling powers over Kutea are, without a doube, China and the United States. Thus, China's own perception of its role in the Korcan peninsula can be best described in the dassical erm as the balancer, the one thar Engtand performed in European politics for centuries.

This attitude on the part of China casts an ominous shadow on the unification of Korect. Lïrst of all. China would not condone any government in the peninsula to chatlenge its legitmacy in mortheasrern provinces, such as Manchuria, where a million Kurcans have resided. Beijing and Pyongyang resoled their conflict wer the common border, especially over Chientao (Kando in Korean) and Mt. Baekdu in the 1960s. However, in South Korea, there is a strong pervasive feeling that these areas belong to Korca. If the rising tide of nationatism in China and its counterpar in a unified Korea collides in the future, in will create the worst situation for both countries. Moreover, as long as China is suspicious of the real intention of the Koreans, it is evident that Beijing would not agree to the Korean unification, or demand the new Korean government to tatify the prescme Sino-North Korcan reaty over their borderline as a prerequisite to its consent for uniticarion. This is why the Korcans in the South should be carcful in raising territorial issues with the Chinese.

Of course, all great powers interested in Korea would preter the present situation of divided and peaceful coexistence of two Koreas to a unified Korea. Unification will inevitably add confusion to East Asian regional politics, with the collapse of North Korea. More importan is the fact that the unified Korea will have a population of over eighry million, which will be a great power only next to Russia and the unified Germany in the European political context. Thus, the powers will not be complacent about the appeatance of a second Japan in East Asian politics. However, it is China that is more likely than orher powers to take a stance against unification. To China, the peaceful unification of Korea, which (hina has supported overtly, means the absorption of the Nortl by the South. This is a step forward to the destruction of the socialist counuries, something China has strenumsly tried to avoid. In the long term, this is a process by which peacefisl colution was broughr about in the sucialist counrries by the libcrating forces, which is a theory the United States expounded in the early days of the Cold War, and seems ro have come crue with the desolation of the Soviet cmpire in Fasrern Furope. The Korean peninsula is the next place where this theory can be applied and this process seems to be achicved at the present time by the Gotterdammentung of Kim's dynany in North Koted Matray 1985). To China. the collapse of North Korca is a nightumatre which implies that Chira itself is the last remaining otjece of rhe long-term conspiracy of the linited States, besides a loss of a socialist ally and strateric partocr.

For Koteans, unification is possible only when Beijing considers that the future Korean reggine will be friendly or that Korea will not be necupied by or under the influence of. 
powers hostile to its security. In this regard. the preoccupation with a sense of isolatienn by the present CCI regime and the conspiracy theory of the Lnied States are not help" ful. This state of mind on the part of the Chinese will open the way for a new Cold War in East Asia, by which confrontation between the great powers will become increasingly intensified, and by which China will nor remain indifferenc towards North Koreas? absorption entemy.

No less important for Korean unification is the democratization of the Chinesc society in gerectial. This aspret, which is refered $w$ in this paper as the 'societal aspect in Chinese forcign policy-making; is particularly germane for the future of Korea. The more the present CCP leadership fecls that the Chinese society is alienated from the social develupment of other countries. the dearer the Kim Jung-il regime in Pyongyang will he tu China. Of course, any Chinese assistance will entail serious risks for Beijing in its relations with Scoul. On the other hand. if China is democtatized due to economic liberalization and participates in the world economic system. China will be relieved by the fricndly milicu in the Last Asian region. It will realize that the new Seoul regime is nor a threat of its security and that the presence of U.S. forces in the peninsula is simply to act as a stabilizer in regional politics. If these forccasss rurn out to he roughly congruent with the emerging reality, then. China may accept the inevitability of a unified Koreas.

\section{REFERENCES}

Bernstein, Richard, and Ross H. Munto. 1997. The Cosning Conflict with China. New York: Alted is. Kiropt.

Bianso, Lucitr. 1971. Origins of the Chinese Retoluton 1915-19\%9. Translated by Muriel Bedl. Stanford: Sunford Unversity Press.

Chen. Qimo. "China-Korean Peninsula Relation in the 21st Century." Paper presented at the International Conference on Korea in the 21 st Century. Senul, Korci, June 3-4, 1997.

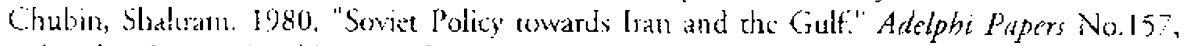
lendors: ]ntcmatiunal Instituse tor Seratcric Sturdies.

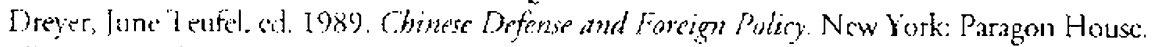

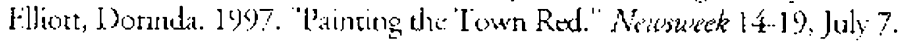

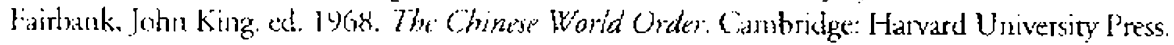

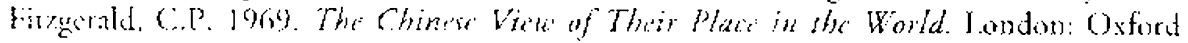
[? niverist 'ress.

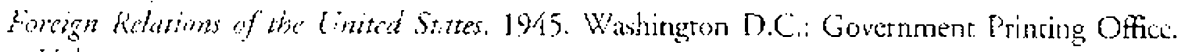
Vot. 6 .

Frestulus, Jr., and W. Chas. 1996. "Sino Amerian Redations: Back on Basics." Forcign Poliay 104, 3-17.

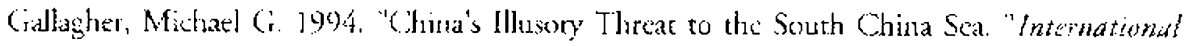
Security $19(1), 16 \%-\%$.

Golwin: Pan! JAR 1996. "From Contiment to Periphery: Pla Doctrine, Sirategy and

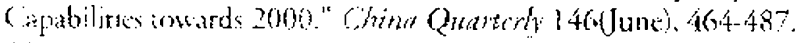

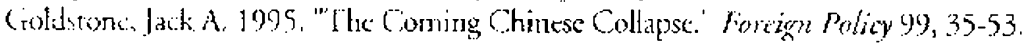

Gurtor, Metwin. I99: "Chinat' Military Mudernization : Implicarions for Security Policy." Paper 
presented at the International Conference on the Future of Chinil and Northeast Asia, May 2223.

Harris, Suarc 1996. "The Tawan Crisis: Some Basic Redities." The China Joumal $36(J u l y)$. 129-134.

Hornik, Richard. 1994. "The Muddlc K"ingdom?-Bursting China's Bubble," Foreign Affairs $73(3), 28-42$.

1 Huarng, Yasheng, 1995. "Wry Chima Will Nor Collapse." Foreign Policy 99, 54-68.

Huck, Arthur. 10) 1. The Serurity of China . Chinese Approaches to Problems of War and Stritegy. Londion: Instrute for Strategic Studics.

Huntington, Samuel P. 1993. "I he ( lash of Civilizations?" Forcign Affairs 7263), 22-49.

Jervis, Robert 1991/92. "I he Fusure of World Politis." Intcrnational Security $16(3), 39.73$.

Toseph. William A. ed. 1997. Chind Briffing- The Contradictions of Change. Armonk. New York: Mí. F. Sharpe.

Kin, Sanned $S .1997$. "The Future of Chind and Sino-ROK Relations." Paper ptesctited at the International Conference on the Future of Chind and Northeast Asia, May 22-23.

Kim, Taeho. 1997. "The Myth of a Hegemonic China: the Miliasy Dimension." Paper presented at the International Conference on the Future of China and Northeast Asia, May 22-23.

Kirkpatrick, Jeant J. 1992. "Atter Communist, Whatt?" Problems of Communism 4.1(1-2), 7-10.

Kissinger, Heny. 1979). White Ifouse' Years. Boston. Lifrle, Brown \& (ompany.

l.ec, Hong Yung. 1997. "China s Triangle with Two Koreas." Paper presented at the International Confetenoe on Korea in the 21 st Century, Seoul, Korea, Jane 3-4.

Malia, Marin. 199?. "Forn Under the Rublble, What?" Problews of Communim 41(1-2). 89. 106

Mastel. (ireg. 1996. "Reijing at Bay." Forcign Poilicy 104, 27-34.

Matray, Janues Irving. 1985. The Reluctant Crusade-American Foreign Policy in Korea, 1941. 1950. Hondulu: Universizy ot 3 Lawain I’ress.

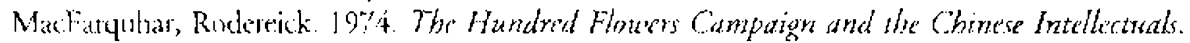
New York: Octigon Books.

Mackeas: Joh:anna 1997. "One Counn', Many Systems." Time 149426) June 30.

Nye, Inseph S. Jr. 1995. "East Asian Security: The Case for Decp Fongagement." Fareign Affairs $7 / 4(4), 9(10.102$.

Nyce [useph \$. J r. 1995. "Relations with China: A Critical Challenge tor the U.S." Backgrounder Deci 20 .

Pak, ['u-bit. 1996. "Ch'sekur] Jungkuk Kunsabi Jung'gaou Kuknae Chongch'ijok Songkyok" I"The Dormestic. Political Implications of Recant Mijtary Budger Increase in China"). In Oekyo Anbo Yonku [joumal of Forrign Affairs and Securityl 1-1 (December).

Sehram, Scaurs R. 1969. The Political Thought of Mao Tsi-tung. Harmondsworth: Penguin Borks.

Segat, Gerakl. 1996. "Fast Asia and the Constrainment of Chima." International Secority 20(4), $10 \div-135$

Shambaugh, David. 1996. "Containment or Fngagement of China?-Calculating Beijing's Responses." International Seitrit)' 21(2), 180-209.

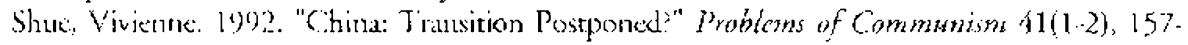
ins.

Sutcr. Ruber G. 1986. Chnise Horizn Policy-Development after Mato. New York: Pracger.

Teng, Ssin-yu, atsd John K. Hairbank, 1971. Chinas Response to the West-A Documentary Sutrcy 1839.1923. Now York: Atuncum.

Terrill. Rows 1992. China in Our Time. New York: Simen \& Sthuster.

Tusker, Naruy Bernkopt, 1996. "War or Peace in the Taisan Straie?" The Washington Quarerly. 
19)(1), 17-187.

X. 1947. "The Sources of Soviet Conduct." Forcign Affarr 25(July), 566-82.

Yahuda, Alichaed. 1978. China's Roie in World Affoirs. London: Groom Helm.

Yahuda, Michael 1983. China': Forrign Polity aft'r Mao-- Touards the End of lsolationism. London: Mactrillans.

7hang, Yongin. 1991. "China's Finty into International Sociecy: Beyond the Standard of (ivilizarion." Reviru of International Stuties $17-1$ (Ian). 